\title{
DEVELOPING AN INTERACTIVE STORYBOOK APPLICATION 'JACK AND THE DIRTY SMELLY BEAST' FOR ENGLISH LANGUAGE PROFICIENCY AMONG CHILDREN
}

\author{
Indah Fakhrani Arpin and Maizatul Hayati Mohamad Yatim \\ Department of Computing, Sultan Idris Education University, Malaysia
}

\begin{abstract}
The high percentage of students who are still struggling with the English language is worrisome, even though there are many well-planned strategies and education policies that are developed to resolve this problem. It is a universal belief that learning a foreign language at a young age through reading plays an important role. Accordingly, the aim of this research is to design, develop and evaluate an interactive storybook application combined with suitable multimedia elements and features to encourage children to read. The interactive storybook entitled 'Jack and the Dirty Smelly Beast' was developed using Instructional System Design (ISD) and Rapid Prototyping model. An experimental study was conducted with 17 respondents between the ages of $6-8$ years to test the effects of the multimedia elements and features in improving children's learning. Their responses were recorded and analysed using descriptive analysis. The findings showed that respondents agreed that learning experience improved significantly and attracted children to read when using this application. In conclusion, by using correct multimedia elements and suitable features in the interactive storybook application, it is envisaged that the children's comprehension in learning a foreign language can be expanded. This research foresees there is enormous opportunity for literacy development in foreign language learning in the early ages through the creation of an interactive storybook application with suitable multimedia elements and features for children.
\end{abstract}

\section{KEYWORDS}

Instructional System Design (ISD), English language proficiency, Rapid Prototyping model

\section{INTRODUCTION}

Learning a foreign language like English, Mandarin, or Arabic has always been recommended to people because it is not only useful for communication but also it opens up ample opportunities for an individual to advance in many fields like education and job prospects. This is especially so with the English language, as it is the dominant language of economics, politics, cultural and social. It is for this reason, Malaysia is promoting the English language so we can modernise the country and become more global than before [1].

The inclusion of the English Language as a subject in the Malaysian education system evolved from the Education Ordinance in 1957 which the government legislated under the national educational policy where they established the national school. Moreover, a great deal of other strategies and policies have been planned and introduced by the Malaysian Ministry of Education (MoE) throughout the history of the education system in Malaysia to improve the English proficiency of students. Some of the examples are 'Pengajaran dan Pembelajaran Sains dan 
The International Journal of Multimedia \& Its Applications (IJMA) Vol.13, No. 4, August 2021

Matematik Dalam Bahasa Inggeris' (PPSMI) which were fully implemented in 2007 and 'Memartabatkan Bahasa Malaysia \& Memperkukuh Bahasa Inggeris' (MBMMBI) in 2010 [2].

Though the main aim for the establishment of PPSMI and MBMMBI is to encourage the use of the English language as a medium of instruction in all primary and secondary schools but still priority will be accorded to the Malay language. This policy enables students to gain wider knowledge of most domain languages and to gain more opportunities in the future. However, the results of the implemented PPSMI and MBMMBI are not as expected. The failure in achieving PPSMI's goals has led to the poor achievement of student's results in Mathematics and Science subject and the wide gap of achievement between rural and urban school students [2]. Moreover, despite the very well planned MBMMBI strategy, there is still a high percentage of students who are still struggling with the English language.

One of the causes of failure is that students do not fully understand the English lessons taught by the teacher. Hence, the teacher has no choice but to use the Malay language to re-explain to them. This shows that teachers are not using the English language fully as expected to do. Starting to learn English at an early age plays a major part since the consequences of a slow start will make it harder and takes more time to learn [3]. Although students are already learning English from the first year of primary school, but success does not come easily due to insufficient time for learning and lack of appropriate learning resources [4]. In addition, students tend not to practice what they have learned after school thus making them less fluent with the language.

The rest of the article is organized as follows. Section 2 describes the review of related literature which also represents the knowledge gap that has been addressed by comparing existing and similar interactive storybook software application projects. Section 3 presents the research methodology used to conduct this research including the execution of seven steps in a Rapid Prototyping model. Section 4 discusses the findings from the data analysed in the user acceptance testing. Finally, Section 5 provides a brief summary of the article.

\section{LITERATURE REVIEW}

This section presents an analysis of the literature in developing an interactive storybook application for English language proficiency among children using Instructional System Design (ISD) and Rapid Prototyping model. It begins with an overview of the interactive digital storybook and its evolution as the source of the research. Next, the following section focuses on the use of multimedia elements in interactive digital storytelling development. Then, the discussion goes on to describe how a digital storybook can help children in literacy development. Finally, the past works of existing interactive digital storybooks are being studied in tandem with learning theory and strategies.

\subsection{Interaction Digital Storybook and Its Evolution}

Storybook or Picture Book is a book which has a combination of words and illustrations (some books only have the image) is intended to deliver specific information or stories. The storybook is mainly written to encourage the children to read. Reading a storybook, whether with the guidance of parents or not, is one way for children to improve their literacy development such as writing and reading [5]. Even till this day, it is still considered an important activity as learning at an early age will reap the benefits of education faster rather than at a later age. One classic example of a popular storybook is 'The Cat in the Hat' created by Dr. Seuss in 1957 which is one of the best-selling children storybooks of all time. There are various kinds of printed storybooks such as 'Board books', 'Concept Books', 'Easy Reader', 'Non-fiction', and 'Wordless Books'. 
The International Journal of Multimedia \& Its Applications (IJMA) Vol.13, No. 4, August 2021

The world of technology has led to a new variety of platforms for reading books such as digital book. Compared to the printed physical book version, the digital book is a storybook that is implemented in digital ways where it can be viewed via an electronic device like smartphones, computers, or tablets. For example, storybooks available in CD-ROM format, incorporate sound, graphics, and text [6]. CD-ROM storybooks are usually being used in schools by teachers as learning materials to help motivate students to learn and increase their participation in learning sessions [7]. Other than that, e-book which is also popular among people after Amazon launched the 'Kindle', an electronic device for reading books in 2007, where people can buy and read an ebook that was offered in the Kindle Store. At that time, many found the e-book reader device to be unique and an ideal way of reading that eventually encourages people to read more than before [6].

Consequently, the digital storybook slowly became more complicated and acquired more features with advances in technology. The digital storybook used to be just a storybook which was directly scanned from printed storybooks without much change in it [8]. But rather than just view, replay and share their stories, digital storybooks now also allow users to activate some of the objects or characters (known as 'hotspots') by tapping on it and some output will pop out. Some of the output likely to pop out are animation, video, sound effect, or even hyperlink [8]. Certain digital storybooks even include games as a side activity to attract the reader's interest, so that they will not lose focus easily. For example, in the Fantastic Flying Books created by Mr. Morris, it allows users to play virtual jigsaw puzzle games where they have to arrange pieces of images given to them to create a complete picture [9].

With the more advanced technology, there are some digital storybooks that come with augmented reality (AR) functions where users can see virtual objects or stories in the real environment through devices that have been used [8]. It is believed, that by using the AR digital storybook, it can encourage users to be more involved in learning and understanding the content easily [10][11].

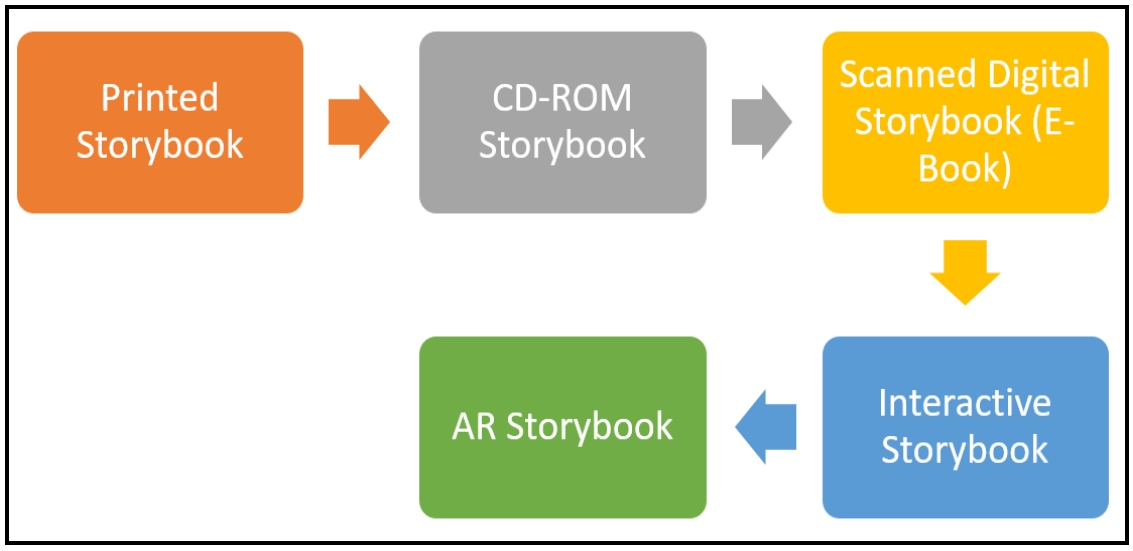

Figure 1. Evolution of storybooks

\subsection{The Uses of Multimedia Elements in Digital Storybooks}

As we know multimedia elements consisting of audio, video, graphic, animation, text, and interactivity, all play a major role in the creation of storybooks, either in printed or the digital format. Compared to normally printed storybooks which usually have at least two elements of multimedia which are text and graphic. Meanwhile, interactive digital storybooks these days almost include all elements of multimedia in it. Though the printed storybook is static and less interactive, surprisingly it still gained more popularity compared to the digital storybook [12]. 
The International Journal of Multimedia \& Its Applications (IJMA) Vol.13, No. 4, August 2021

To keep the reader's attention and maximise their experience while reading the storybook, various multimedia elements should be included because each of the elements will be fully utilised when linked to one another. For example, the video storybook by Weston Woods focuses more on the camera qualities; like panning and zooming to the illustration plus with the help of sound effect, the reader will understand more about what is happening to the story at that time. Features in a digital storybook-like Read Aloud or Voice-over Narration also shows how sound element can help the reader to understand the story better. This can be achieved by focussing on the illustration as compared to when they first read the printed storybook where they have to divide their attention between text and illustration [13].

Though using various multimedia elements is good for the reading experience, the storybook designer should be careful and decide on the vital elements they want the reader to focus on. For example, whether they want the reader to focus on the story or the illustration in it. The findings in past research have shown that young children are more likely to spend their reading time focussing on illustrations rather than the text area since the illustration captures their attention more [14]. The designer should use other alternative or add new features if the reader wants to focus on other text such as highlighting or pointing to the words that have been read. This helps the reader not to lose track and eventually connect the text with the audio [9][14].

In certain situations, too many multimedia elements crammed into one page of the storybook might mislead the readers. Unnecessary features might distract the reader's attention and break the flow of the story which will surely interrupt reading comprehension [15]. Many designers include an interactive element or 'games' inside their digital storybook apps that have no relevance to the content or to the storyline at all, like what happened in The Flying Books storybook. No matter how effective is the feature, it is better to add elements that can provide a perfect correlation with the story and does not disturb the learning process [9][15].

\subsection{Digital Storybook Helps Children in Language Literacy Development}

Literacy skills is the ability to read and write which means children not only can understand the text but can also construct words that have meaning [16]. It is an accepted fact that, reading books and storytelling activities are being practiced by most parents or teachers as these are early childhood education development techniques that are intended to support early development of literacy skills. Additionally, the power of storytelling has the potential to develop or implant good characteristics or morale in children [6]. The numerous studies that have been conducted also proved that the practice of reading storybooks and listening to storytelling at a very young age can contribute significantly to early literacy development. Furthermore, it has been proven that to achieve good development of their literacy skills, either the parents or teachers must make sure that the child enjoys the reading process, as in this manner, it will help shape the child's emotions and moods [17].

\subsection{Review of the Existing Application}

There are several existing applications in the market that can perform similar functions which have been proposed as project ideas. Some of these are:

\subsubsection{Wanderful Storybook}

Wanderful Storybook created by Wanderful company, originally published as Living Books, are designed for kids as an educational application to engage children's mind and build interest for language and reading. This application is available on IOS Apps, Android, OS X Apps and are now exploring Windows platform. Wanderful Interactive Storybook, as shown in Figure 2, is an 
The International Journal of Multimedia \& Its Applications (IJMA) Vol.13, No. 4, August 2021

interactive animated application where there are pictures and characters that can talk and move. One of the special features in this application is that each page is fully animated and interactive and almost everything on the page and certain animation will come to life when the user taps on it [18].

\subsubsection{Hare \& Tortoise: The Interactive Storybook}

Hare \& Tortoise: The Interactive Storybook is a children's interactive storybook is equipped with games application that encourages reading. It is a new bedtime story from RIRI which is a series of interactive children's books with the theme of Indonesia folklore [19] and fables from around the world. This story tells about the race between the proud Hare and the humble Tortoise. As shown in Figure 2, this interactive storybook is packed with animation, sound effects, music, and even educational games so that children will be more interested in the story. To make it easily understood by children, this app uses mild language too [20].
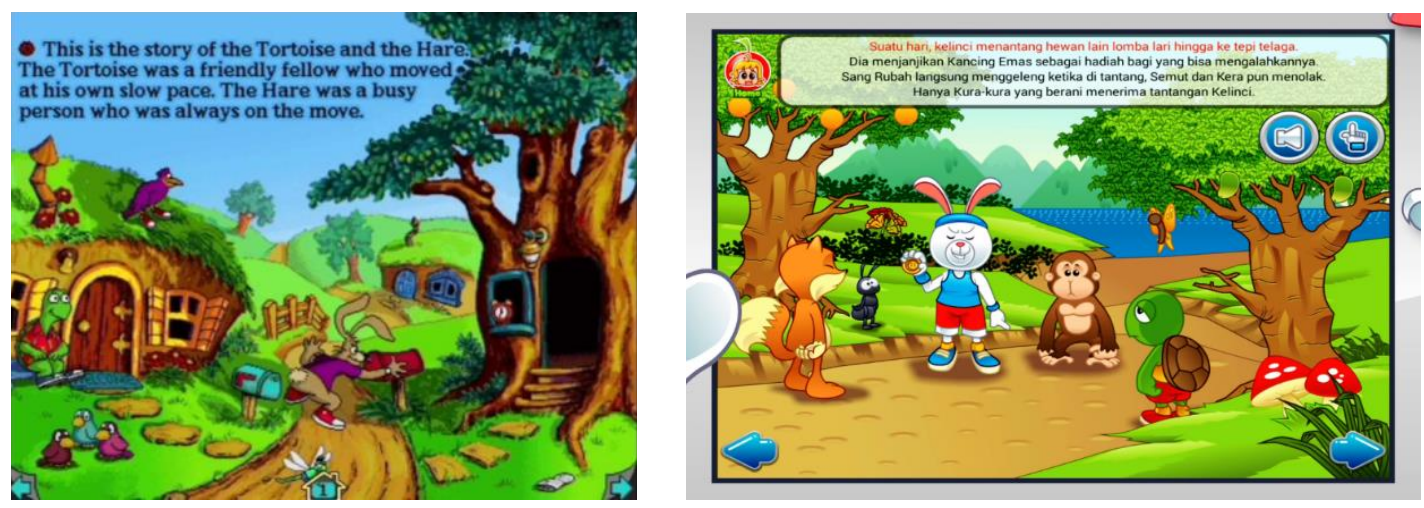

Figure 2. Reading Mode Interface in Wanderful Storybook (left) and Hare \& Tortoise (right)

\subsubsection{Lucy \& Pogo Animal Storybook}

Lucy \& Pogo is an educational application created by Fox and Sheep Agency for children between 3 to 7 years old. In this app, children will learn valuable morale through its wonderful story about Lucy, the cat, who cannot go to the school where Pogo, the dog, went to since it is only meant for dogs. From the story, children can learn how to overcome prejudices, empathy and eagerness to learn from this story. Children will also learn counting, spelling, music and more through mini games that have been prepared in these apps. Handmade illustration (as illustrates in Figure 3) and beautiful pieces of music by film composers make it more interesting to attract children's attention [21].

\subsubsection{Sleepy Mole's Moving Day}

Sleepy Mole's Moving Day is an interactive story application created by Ginger Whale in 2011 which tells the story of a sleepy mole who needs to look for a new place to rest due to construction works near his burrow. This app allows users to choose their own story path that has been prepared for every scene which means they get a new story each time they read this story. This app has prepared 8 possible new homes plus 16 other animals or creatures the child could meet on his journey by clicking which direction for the Mole to dig through. The challenge is to meet all the creatures in this app [22]. The main page of this app can be seen in Figure 3. 

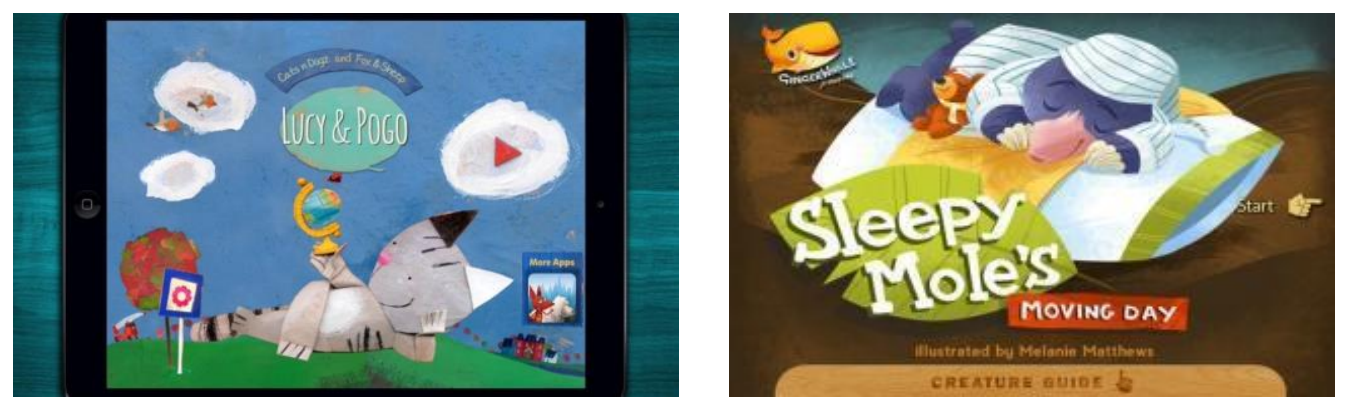

Figure 3. Main page of Lucy \& Pogo Animal Storybook (left) and Sleepy Mole's Moving Day (right)

Table 1 shows the comparison between the existing applications that have been listed before. The aspect that will be compared is the platform they use, the features that can be used, also the advantages and disadvantages of that application.

Table 1. Review of the existing application.

\begin{tabular}{|c|c|c|c|}
\hline $\begin{array}{c}\text { Software } \\
\text { Name }\end{array}$ & Platform & Features/Advantages & Disadvantages \\
\hline $\begin{array}{l}\text { Wanderful } \\
\text { Storybook }\end{array}$ & $\begin{array}{l}\text { IOS, MacOS, } \\
\text { Android }\end{array}$ & $\begin{array}{l}\text { Fully animated and Interactive } \\
\text { page (even the words). } \\
\text { Has hidden surprise on each page. } \\
\text { Narrated in multiple languages } \\
\text { (English and Spanish). } \\
\text { Can customize reading experience } \\
\text { setting. }\end{array}$ & $\begin{array}{l}\text { Too many interactive things that } \\
\text { might distract the reader's } \\
\text { attention. } \\
\text { Must pay to get an extra story. }\end{array}$ \\
\hline $\begin{array}{l}\text { Hare \& } \\
\text { Tortoise - } \\
\text { Interactive } \\
\text { Storybook }\end{array}$ & Android & $\begin{array}{l}\text { Can choose whether Narrative } \\
\text { storybook mode or Read Alone } \\
\text { mode. } \\
\text { - } \quad \text { Interactive characters and objects. } \\
\text { Have } 4 \text { different type of } \\
\text { educational games. }\end{array}$ & $\begin{array}{l}\text { The font size of the story text is } \\
\text { too small. } \\
\text { Some of the mini games in this app } \\
\text { are not related to the main story. }\end{array}$ \\
\hline $\begin{array}{l}\text { Lucy \& Pogo } \\
\text { Animal } \\
\text { Storybook }\end{array}$ & IOS & $\begin{array}{l}\text { - Fully narrated in } 5 \text { languages. } \\
\text { 13 lovely animated films and mini } \\
\text { games. } \\
\text { Based on the popular children's } \\
\text { book "Le chat qui aboyait". } \\
\text { - Well-developed story that teaches } \\
\text { good morale value. }\end{array}$ & $\begin{array}{l}\text { There's no text section for the } \\
\text { reader to read. }\end{array}$ \\
\hline $\begin{array}{l}\text { Sleepy Mole's } \\
\text { Moving Day }\end{array}$ & IOS & $\begin{array}{l}\text { Choose your own journey. } \\
\text { Have various kinds of } \\
\text { stories/ending depend on your } \\
\text { choice you made. } \\
\text { Illustrations from award-winning } \\
\text { artist Melanie Matthews. } \\
\text { - Narration in English and Swedish. }\end{array}$ & $\begin{array}{l}\text { Readers have to repeat the story } \\
\text { every time they are looking for a } \\
\text { new storyline. }\end{array}$ \\
\hline
\end{tabular}

\subsection{Learning Theory and Strategies}

To achieve maximum effectiveness when using the Interactive Storybook application, learning theory and learning strategies have to be applied, together with suitable learning content and user's characteristics. For this kind of application, the Cognitive Theory of Multimedia Learning is a more appropriate theory that can be applied. Cognitive Theory of Multimedia Learning is a theory where it believes that the learning process will be more successful if various multimedia elements like picture and audio are being used together rather than just the text [23]. Not only does multimedia make it easier to remember and understand the content, but it also helps people to stay focused as multimedia is always being used as teaching tools by the educator [24]. 
The International Journal of Multimedia \& Its Applications (IJMA) Vol.13, No. 4, August 2021

Meanwhile, the learning strategies that will be used in this application are problem-based learning, Storytelling and Feedback strategy. Problem-based learning strategy not only helps learners recall what they have learned earlier, but it also makes the learner want to apply the information when facing such a situation. This also directly leads to an improvement in problem skills like analysing the problems more carefully before solving it. The feedback strategy eventually will be applied when the learner is successful in solving the problem they have been receiving. They will be more motivated and appreciated when they get proper and meaningful feedback [25][26].

Other than that, storytelling strategy is one of the strategies that are mostly used to help children learn new things [27]. There is a study where it shows that children learned well from storytelling because the good presentation of the story helps them learn to absorb new information better [28].

\section{METHODS}

This section discusses the research methodology used to conduct this research. Acting as a guide for this research, the main purpose of the methodology is to ensure that all the specific tasks can perform directly within the scope of the research. As stated, the aim of this research is to design, develop, and evaluate an interactive storybook application combined with suitable multimedia elements and features to encourage children to read.

Based on the issues above, it is believed that an early start and having more time to learn English plays a crucial part. The main goal of this research is to develop an interactive storybook application entitled 'Jack and the Dirty Smelly Beast'. The application was designed and developed for English language proficiency mong children using ISD and Rapid Prototyping model. In order to achieve this goal, the following objectives must be completed:

- To identify the multimedia element that is suitable in a digital storybook;

- To identify the suitable features that can stimulate users to learn; and

- To analysis the user acceptance when using digital storybook.

\subsection{Research Scope}

The scope of this research will focus on children who wants to learn English language as their second language. Primary school students, who are between $6-8$ years old will be chosen as research participants because, at that range age, they have already started to learn and read more fluently. This research will be conducted among the students from one of the primary schools located at Batu Caves, Selangor, Malaysia, in the 2020-2021-year session.

\subsection{Selection of Instructional System Design Model}

Instructional System Design (ISD) or Instructional Design (ID) model is a model or approach used to design an instructional product which focuses on searching the best learning strategies and content for the target learners. The different phases in the model mostly analyse the learner so that the best requirement for their product can be derived. Table 2 summarizes the advantages and disadvantages of existing ISD model. 
The International Journal of Multimedia \& Its Applications (IJMA) Vol.13, No. 4, August 2021

Table 2. Review of the existing application.

\begin{tabular}{|c|c|c|}
\hline Model Name & Advantages & Disadvantages \\
\hline ADDIE & $\begin{array}{l}\text { - Sequenced model. } \\
\text { - } \\
\text { - Moquirement is well defined. } \\
\text { modelled. }\end{array}$ & $\begin{array}{l}\text { - Must complete one phase before } \\
\text { continuing to next. } \\
\text { - Might be time consuming since } \\
\text { each phase must be fully satisfied } \\
\text { before continuing another phase. } \\
\text { - Not good for undefined } \\
\text { requirement projects. }\end{array}$ \\
\hline ASSURE & $\begin{array}{l}\text { Good in finding requirement, } \\
\text { objectives and guidance of } \\
\text { the courseware. }\end{array}$ & $\begin{array}{l}\text { - Time consuming. } \\
\text { - Need very detailed requirement } \\
\text { and research. }\end{array}$ \\
\hline $\begin{array}{l}\text { Rapid } \\
\text { Prototyping }\end{array}$ & $\begin{array}{l}\text { - Easy to get feedback from the } \\
\text { user. } \\
\text { - Avoid extra cost and time } \\
\text { when defects are found } \\
\text { earlier. } \\
\text { - Actively involve the user. }\end{array}$ & $\begin{array}{l}\text { - Might be time consuming in the } \\
\text { prototype development phase. } \\
\text { - Users might confuse between } \\
\text { prototype and finished } \\
\text { courseware. }\end{array}$ \\
\hline ARCS & $\begin{array}{l}\text { Easy to apply and actively } \\
\text { involve learner participants. } \\
\text { - Good for analyzing learner } \\
\text { motivation and finding } \\
\text { suitable learning techniques. } \\
\text { Mainly used to increase } \\
\text { learner motivation to learn. }\end{array}$ & $\begin{array}{l}\text { - Hard to find a suitable approach } \\
\text { or technique that fit all } \\
\text { requirements from the learner. }\end{array}$ \\
\hline
\end{tabular}

To understand these models, a table of comparison between various ISD models have been created as shown in Table 2 to help select the most suitable ISD model for the certain project. The various aspects need to be carefully checked before choosing a model. For example, the due date of the project, budget, sufficiency of user's requirement, developer's skills and many more things that need to be considered carefully so that the project will proceed smoothly.

After considering many of the aspects, the ISD model chosen to develop the courseware is the Rapid Prototyping model because to develop interactive storybook applications need a lot of feedback from potential users. So, we can observe them when testing the prototype and see how good that application is in helping the users to learn something. Importantly, we must observe the effectiveness of the learning strategy and features in the application when used by the users [29]. Every evaluation result will be used as a reference to develop a better and efficient application later.

There are several advantages and disadvantages when using Rapid Prototyping Model. Some of the advantages include continuously receiving feedback from potential users' every time a new prototype is created. The feedback from the users will help improve the courseware and repair the faults that are found when an evaluation of the prototype is conducted. This eventually helps cut cost and time in the later phase because the requirement for the courseware is enough and precise and the risk to find new faults or errors are less. However, if the prototype is not well designed, it might lead to confusion of the users on what actually the courseware will look like [27]. In some of the cases, users have a misunderstanding when they thought the prototype is the real courseware which leads to disappointment when, in fact, the real courseware comes out differently compared to that prototype. 


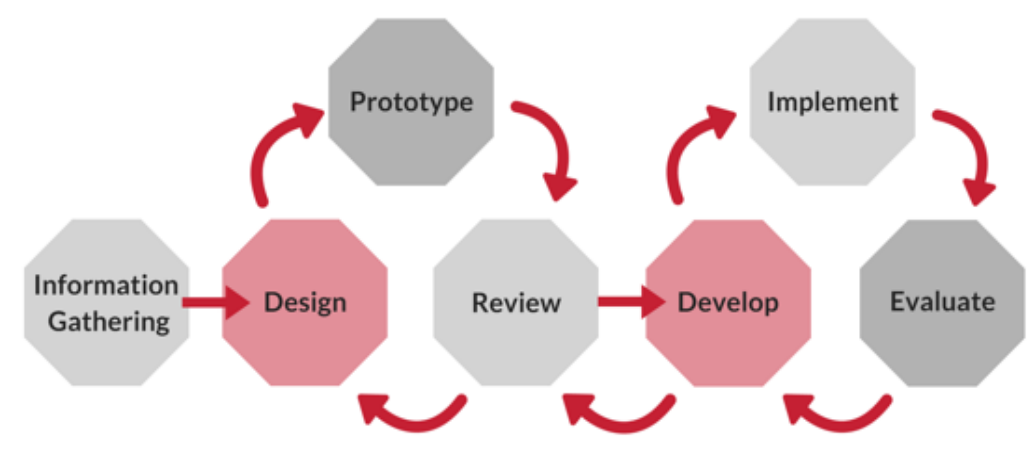

Figure 4. A diagram of Rapid Prototype Model

The ISD model that has been chosen for this project is the Rapid Prototyping model, as illustrates in Figure 4. The Rapid Prototyping model is an iterative approach when designing the product. Rapid prototype models mostly involve the users many times since they need to review every new prototype developed so they can find the faults of the application or what needs to be improved to make it better. There are seven steps in a Rapid Prototyping model with the purpose to reduce the amount of time needed to develop the interactive storybook application in this research. Upon conducting these steps, the potential limitation or deficiencies observed which happens in any steps are being taken into consideration.

\subsubsection{Step 1: Information Gathering}

In this phase, the detailed requirement of the courseware will be collected from the possible user. The requirement will be collected through a different technique like brainstorming, document analysis, and prototyping. All the gathered information will be analysed so the requirement needed for the courseware will be captured.

\subsubsection{Step 2: Design}

A quick sketch or storyboard of the courseware will be created based on the requirement that has already been analysed. The purpose of this phase is to show how the courseware will work, which part of the courseware will be applied with the learning strategies and what type of media will be used. The user interface of the courseware will be created after the storyboard is approved and confirmed by the users so we can see a more realistic image of the courseware that will be developed. This quick design is mainly used as reference for the developer and will also give the user a brief idea about the courseware.

\subsubsection{Step 3: Prototype}

After the quick design has been approved, a prototype will be developed based on it. With the prototype, the user can see how the real courseware will look like and how easy it is to gather more requirements for the part that needs to be fixed. A new prototype will be developed after getting feedback from the user in the Review phase. The new prototype will be improved based on the feedback and suggestions given. This phase not only helps in finding the missing needs of the product but also saves time and cost by finding error or fault in the prototype early. The new prototype will be shown to the users for the review again. Both phases will be repeated until the current prototype is close to the expectation and all the users are satisfied with it and this phase might take a longer time than expected. 


\subsubsection{Step 4: Review}

After having built a prototype of the courseware, the initial review session by the user must be conducted to make sure it satisfies the requirement that has been collected during the requirement analysis phase. Also, in this phase, we can find out about the weakness that needs improvement and strength of the courseware. The users who are involved in this phase are mostly potential end-users and developers of the courseware. The aspect that will be checked in this review is mostly on design, functions, and the flow of the courseware. All the feedback and suggestions will be recorded for future reference should the courseware needs to be improved.

This phase will be conducted every time a new version or edition prototype is developed and will only proceed to the next phase when all the users are satisfied with the current prototype. This process, known as iterative process, means the current prototype will continually be improved by the application developers in collaboration with the subject matter experts (SMEs), i.e. educators.

\subsubsection{Step 5: Develop}

The development phase is where the developer will turn the design into the real courseware. Mostly, this involves coding and creating media such as animation that is needed for the courseware. Software tools for developing the courseware will be chosen based on the developer's ability and types of systems that will be developed later.

\subsubsection{Step 6: Implement}

After developing the courseware and having done pre system testing, the courseware should be deployed to the learner environment so they can use it.

\subsubsection{Step 7: Evaluate}

Then, the final evaluation will be conducted to check whether the courseware has achieved the objective and user satisfaction when using the courseware. The evaluation will be conducted as a summative evaluation.

\subsection{Project Management for Prototype Development}

In this section, all the activities in each phase of the Rapid Prototype will be shown through the Gantt Chart. The commencement of this project is in the middle of August 2020 and finished in early January in 2021.

The rest of the explanation will show how the application works based on the requirement that has been analysed before reviewing the behavioural and architecture diagrams.

\subsubsection{Functional Requirement}

There are three main modules which are Story module, Vocabulary module and Quiz module that the user can use. In the Story module, the user is able to view the story and at the same time, he can interact with characters on the story page and listen to the narration of the story. Other than that, the user can view vocabulary words, solve the quiz and check the answers from the feedback received. 
The International Journal of Multimedia \& Its Applications (IJMA) Vol.13, No. 4, August 2021

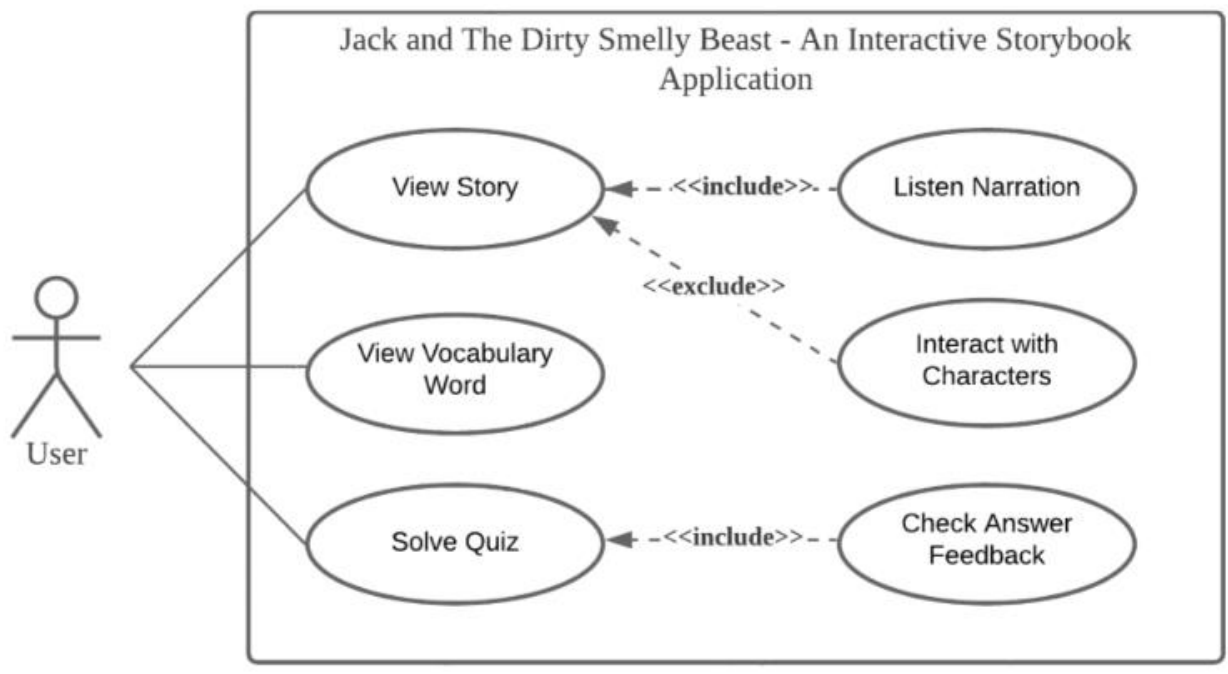

Figure 5. Use Case Diagram of 'Jack and the Dirty Smelly Beast'

\subsubsection{MVC Architecture}

The chosen architecture style for this application is Model-View-Controller (MVC) because it is an interactive application that requires incorporation of human computer interface. Systems are decomposed into three main types of components which are Model, View, and Controller, as shown in Figure 6.

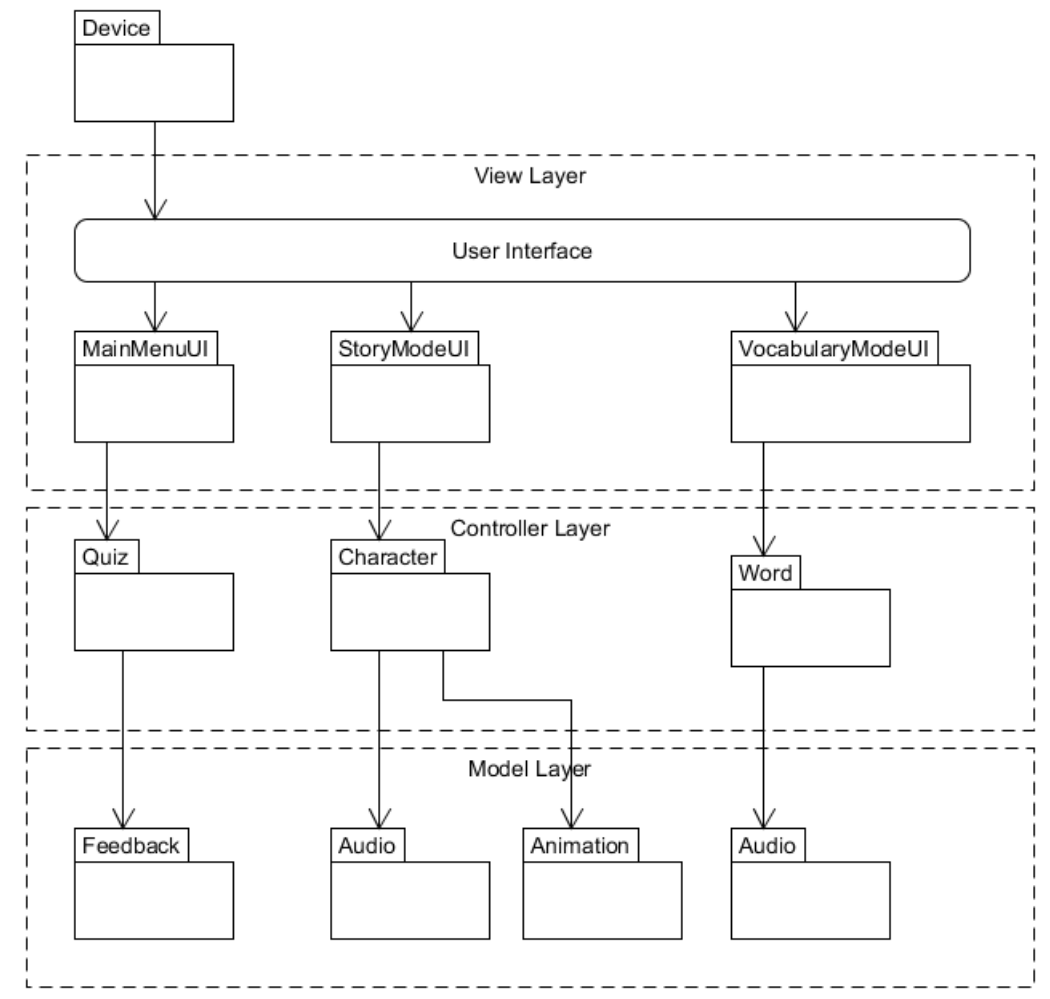

Figure 6. MVC Architecture Diagram 


\subsubsection{User Interface}

Figure 7 (left) shows the main page of the 'Jack and The Dirty Smelly Beast' application which shows the title of a story and main characters of it which are 'Jack' and 'Beast' where they pop out right after user open the application.
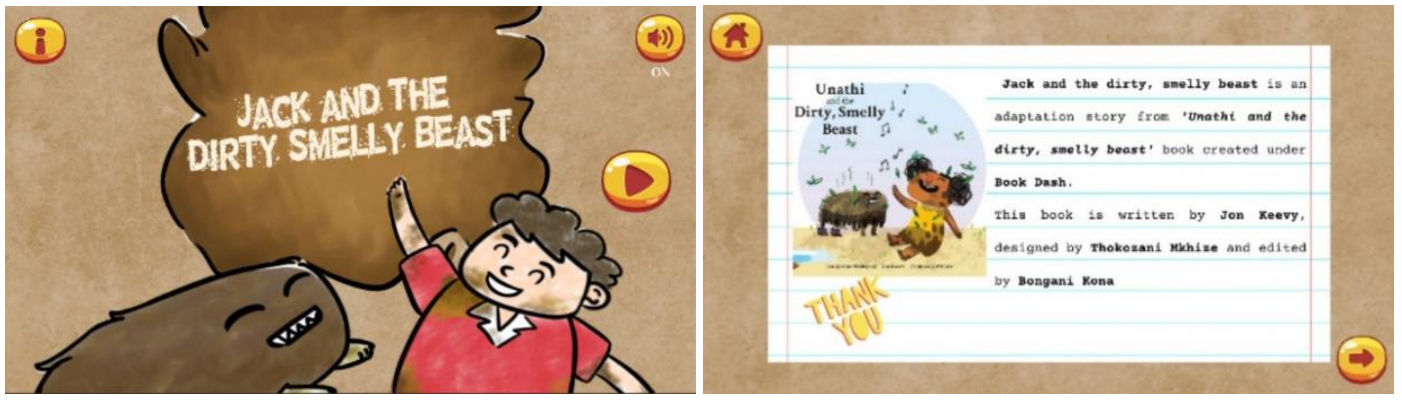

Figure 7. Main Menu Interface (left) and Info Interface (right)

There are three buttons on the main page. Two of which are, Music and Info buttons, which are placed on top of the right and left corner of the page. Meanwhile, the Start button is placed at the side of the page so it won't merge with the title image.

When the user clicks the Info button on the main page, it will direct the user to the information interface (as depicted in Figure 7 (right)), which contained details about the original storybook, for example, the name of the writer and illustrator. There are two buttons in this interface which are the Home button, which will bring the user back to the main page and the Next button to view more information.

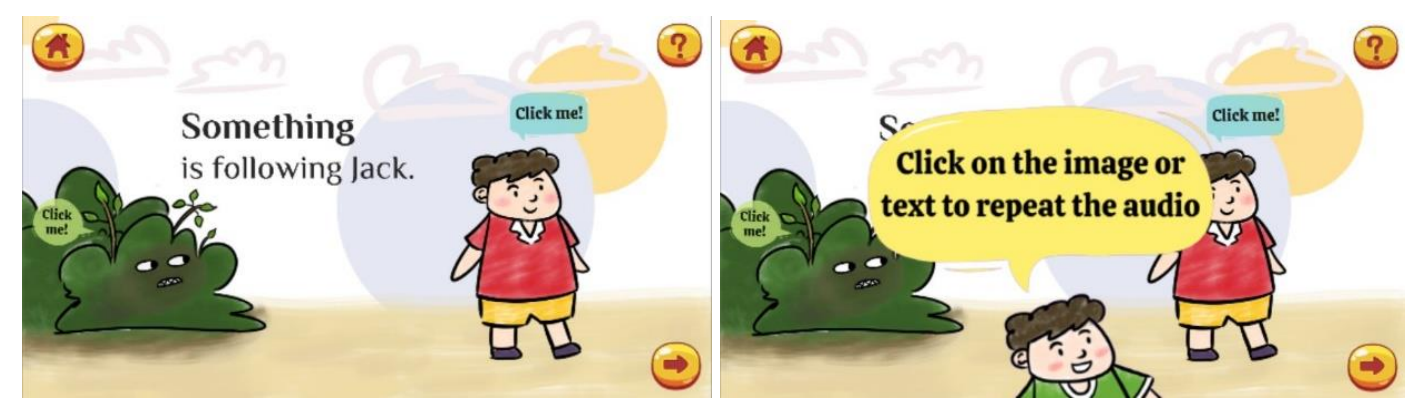

Figure 8: Story Mode Interface (left) and Story Mode Interface - Hint Message (right)

Figure 8 (left) shows the first page of the Story mode. The interface design of the main menu contained the illustration of the story together with the story text. In addition, there are various other buttons which are the Home button, Next button, Back button and Hint button. Both the Next and Back buttons are placed at the bottom right and left corner of the screen which bring the user to a certain story page.

The Hint button which is located at the top right of the screen shows the user the hint about clickable characters and text which can play animation and sound effect/narration when the user clicks on it. The hint message pops out in the chat bubble shape along with a character, Jack, to make it more attractive as shown in Figure 8 (right). Meanwhile, the 'Click me!' chat bubble also pop out to make the user click on the hotspot area. Most of the Story mode interface has similar interface design concept. 


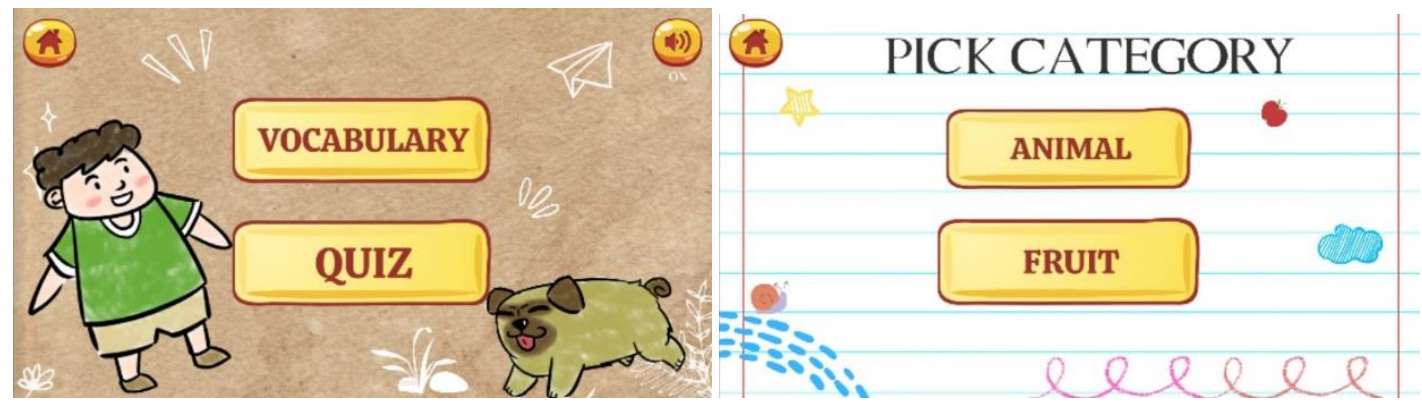

Figure 9. New Main Menu Interface (left) and Vocabulary Mode Interface (right)

Figure 9 (left) shows the interface after the users finished the Story mode. The background design is inspired by old paper with some doodle drawing to make it look more interesting to young children. In addition, it has two main characters of the story which move around it. There are two common buttons, Home button and Music button which are located at the top corner. The main focus of the page consists of the Vocabulary button and Quiz button which are placed in the middle so it can be seen instantly. The Vocabulary button will bring the users to Vocabulary mode whereas the Quiz button will bring them to Quiz mode.

Vocabulary Mode interface started with choosing the category interface. The users have to choose between Animal button or Fruit button, as shown in Figure 9 (right), which leads to the category of vocabulary they want to learn, whereas the Home button is also included at the top left of the page that connects to the new main page.

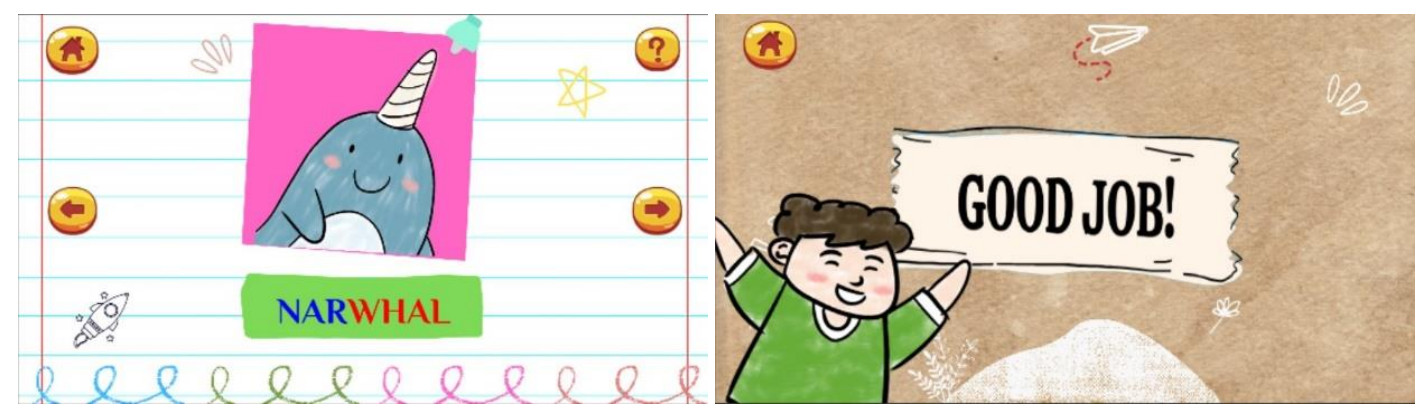

Figure 10. Animal Vocabulary Interface (left) and Vocabulary Feedback Interface (right)

Figure 10 (left) shows the example of Animal vocabulary category user interface. The background is designed to look like a typical school notebook with some of the colourful doodles at the bottom area. The image of vocabulary words is placed in the middle of the page along with the text box which is placed beneath it. The user interface comprised of five clickable buttons which are the Home button, Hint button, Next button, Back button and the image button. The common button is placed at the usual spot meanwhile the image button is placed at the middle of the page. The image is clickable which will produce pronunciation sound of the vocabulary word. The text box is placed below the image to show the spelling of it and every syllable have a different colour so it can help the user pronounce it easily.

After having learned all the vocabulary words, the user will be directed to the feedback interface, as shown in Figure 10 (right), where he will be congratulated for successfully learning all the words. 


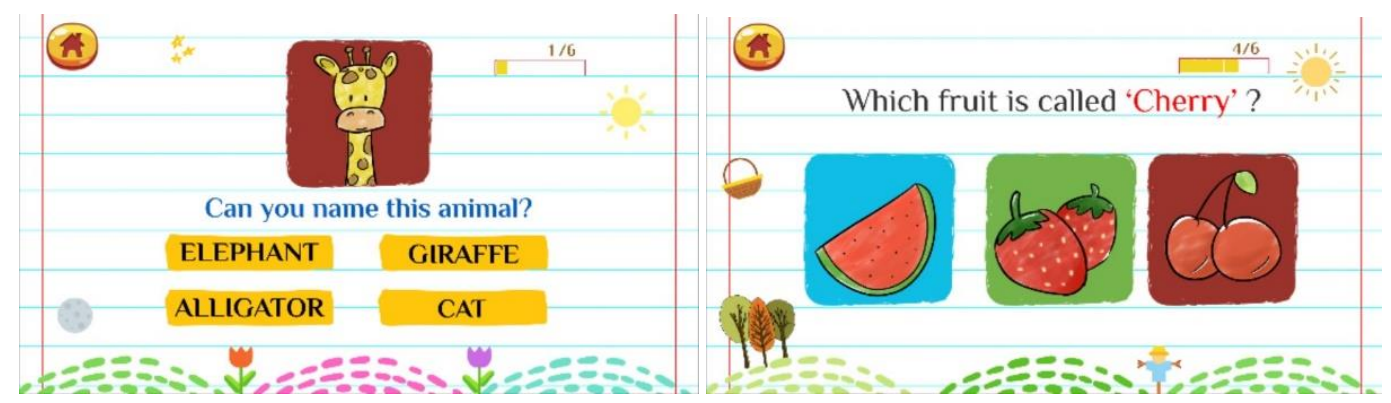

Figure 11. Animal Quiz Interface (left) and Fruit Quiz Interface (right)

The Figure 11 (left) shows the example of the quiz interface for the animal category. In the quiz interface, four answer buttons are lined up below the question text and image along with the Home button at the top left corner. At the top right end of the interface, there is a Progress Bar to show the user how many questions have already been solved. The bar will be added every time they get the correct answer.

Meanwhile, other design of the quiz interface can be referred to the Figure 11 (right). The difference is there are three image buttons for the answer rather than the text button. The user has to click the image based on the question given.
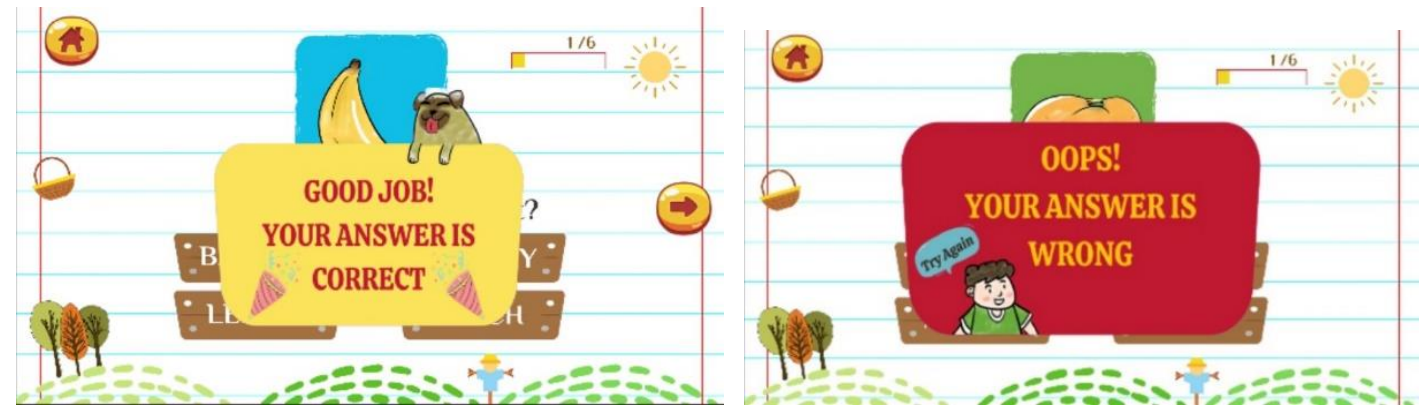

Figure 12. Correct Answer Feedback Interface (left) and Wrong Answer Feedback Interface (right)

After the user clicks the answer button, the feedback message will pop out based on the answer they choose. The feedback message comes out in the shape of a rectangular box with the text and some illustrations on it. When the user answers correctly, a yellow box with the word "congratulation", as shown in Figure 12 (left), will pop out along with the Next button so they can continue with the next question. If the answer is wrong, the red box, as shown in Figure 12 (right), will come out to notify them that they got the wrong answer and after that, it will disappear so the user can try to answer it again.

\subsection{User Acceptance Test}

To answer the third objective of this research, i.e. to analyse the user behaviour when using digital storybook, a user acceptance testing session was conducted once the application has been finalised. For this purpose, a group of children was selected as the respondents for this user acceptance testing. The objectives for the testing session is to analyse the children's acceptance towards the 'Jack and The Dirty Smelly Beast' application in terms of Interface Design and Content section, Functionality section, and the Conclusion section. The following sub-section informs the number of respondents participated in the testing session and describes the questionnaire used as the instrument used for data gathering purposes. 


\subsubsection{Respondents}

A total of 17 respondents participated in the software testing with age ranging between 8-10 years old. With the help of their parents or guardian, the respondent will answer the questionnaire using Google Form which has previously been shared and explained earlier to the respondents and their parents or guardian. The respondents answered the questionnaire upon their acceptance of the application for testing.

\subsubsection{Instrument}

A questionnaire is being chosen as a research instrument for this project. The questionnaire is created by using Google Form which has been shared with the respondent through the link. The questionnaire contained four sections, which are, Respondent Details Section, Interface Design and Content Section, Functionality Section and Conclusion Section. The results of the finding are collected and analysed using descriptive analysis method which is based on percentage. Most of the questions are Likert scale survey questions so that the evaluated data will be more precise. Table 3 shows the 5-Point Likert Scale that is used in the questionnaire.

Table 3. 5-Point Likert Scale.

\begin{tabular}{cc}
\hline Scale & Answer \\
\hline 1 & Strongly Disagree \\
2 & Disagree \\
3 & Neutral \\
4 & Agree \\
5 & Strongly Agree \\
\hline
\end{tabular}

\section{RESULTS AND DISCUSSION}

As mentioned, the data analysed in the user acceptance testing were analysed using descriptive analysis method. The following section describes the findings for the four sections, i.e. Respondent Details Section, Interface Design and Content Section, Functionality Section and Conclusion Section.

\subsection{Findings on Respondent Details Section}

Demographically, the 17 respondents who participated in the software testing were aged between 6 to 8 years old. With the help of their parents or guardian, the respondent will answer the questionnaire using Google Form which has been shared before. The respondents will answer the questionnaire upon their acceptance of the application right after they tested the application.

Table 4. Demography Data.

\begin{tabular}{cccc}
\hline Age & Boys & Girls & Total Respondents \\
\hline 6 & 4 & 4 & 8 \\
7 & 3 & 0 & 3 \\
8 & 3 & 3 & 6 \\
\hline Total & $\mathbf{1 0}$ & $\mathbf{7}$ & $\mathbf{1 7}$ \\
\hline
\end{tabular}

Based on Table 4, the total number of respondents who participated in the user acceptance testing were 17 respondents. Majority of the respondents were aged 6-year-old (47\%) with the lowest at aged 7 -year-old totalling only $18 \%$ altogether. The rest of the respondents was from the age of 8 year-old (35\%) with the majority being boys (59\%) and the remaining, $41 \%$ were girls. The following section shows the findings on interface design and content of the application software. 
The International Journal of Multimedia \& Its Applications (IJMA) Vol.13, No. 4, August 2021

\subsection{Findings on Interface Design and Content Section}

Table 5 and Figure 13 respectively show the result for Interface Design and Content section. About $68.8 \%$ of respondents strongly agree that the font size and type used are easy to read whereas $81.3 \%$ strongly agree that the colours used are appropriate too. Meanwhile, $87.5 \%$ of the respondents strongly agree that buttons are clearly visible, and $62.5 \%$ of respondents also strongly agree that the layout design is user friendly and also easy for navigation. Majority of the respondents, about $68.8 \%$, strongly agree that the background sound and sound effect are appropriate, and the narration of the story is clear. Other than that, $62.5 \%$ of the respondents strongly agree that the illustration or the graphic help to understand the story and the learning content more, also the storyline is easy to understand and very entertaining to read.

Table 5. Result Finding of Interface Design and Content Section.

\begin{tabular}{|c|c|c|c|c|c|c|}
\hline & \multirow[b]{2}{*}{ Question Item } & \multicolumn{5}{|c|}{ Scale } \\
\hline & & $\begin{array}{l}\text { Strongly } \\
\text { Disagree }\end{array}$ & Disagree & Neutral & Agree & $\begin{array}{c}\text { Strongly } \\
\text { Agree }\end{array}$ \\
\hline a) & The font's size and type used is easy to read. & 0 & 0 & 0 & 31.3 & 68.8 \\
\hline b) & The colours used are appropriate. & 0 & 0 & 6.3 & 12.5 & 81.3 \\
\hline c) & Buttons are clearly visible. & 0 & 0 & 0 & 12.5 & 87.5 \\
\hline d) & The layout design is user friendly and easy to navigate. & 0 & 0 & 0 & 37.5 & 62.5 \\
\hline e) & The background sound and sound effect is appropriate. & 0 & 0 & 12.5 & 18.8 & 68.8 \\
\hline f) & The story's narration is clear. & 0 & 0 & 6.3 & 25 & 68.8 \\
\hline g) & $\begin{array}{l}\text { The illustration/graphic help to understand the story } \\
\text { /learning content more. }\end{array}$ & 0 & 0 & 6.3 & 31.3 & 62.5 \\
\hline h) & $\begin{array}{l}\text { The storyline is easy to understand and entertaining to } \\
\text { read. }\end{array}$ & 0 & 0 & 6.3 & 31.3 & 62.5 \\
\hline
\end{tabular}

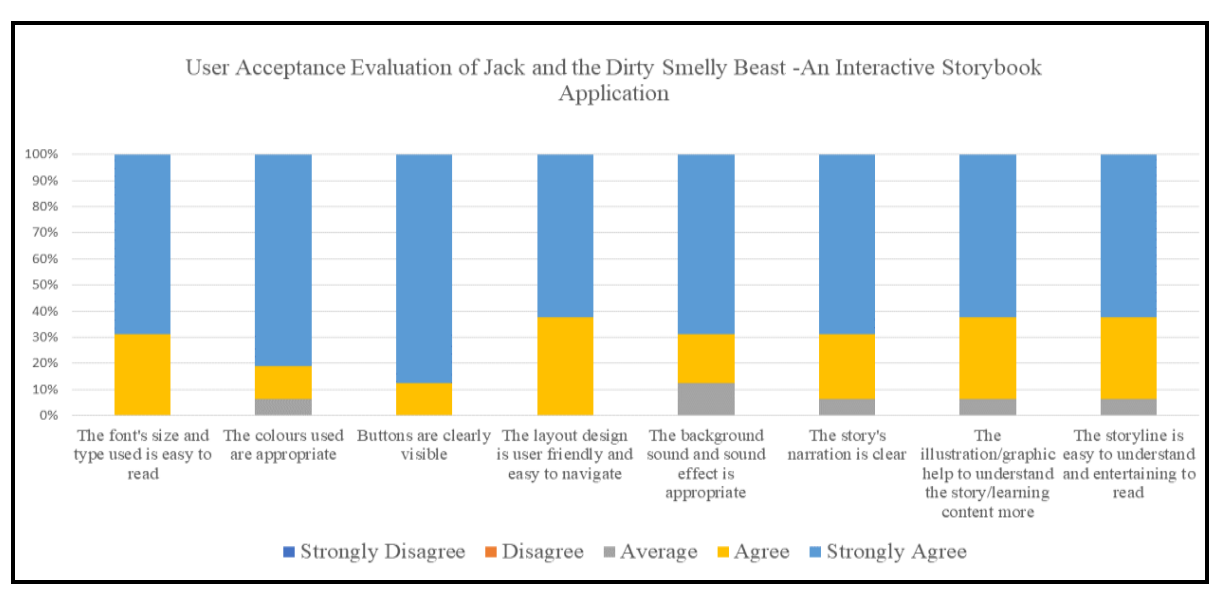

Figure 13. Bar Chart of Interface Design and Content Section Results

\subsection{Findings on Functionality Section}

Table 6 and Figure 14 respectively show the result for the functionality section of the questionnaire. A total of $56.3 \%$ of respondents strongly agree that the animation of characters helps attract children to read whereas only $37.5 \%$ of respondents agree. Other than that, $68.8 \%$ of the respondents strongly agree and $25 \%$ of the respondent agree that the content in the 'Alphabet' feature is useful and easy to learn new words. For the 'Quiz' feature, majority of the respondents totalling $68.8 \%$, strongly agree that it helps to remember the words they have learned from the 'Alphabet' feature leaving only $6.3 \%$ of the respondents who disagree with it. Besides that, $75 \%$ 
The International Journal of Multimedia \& Its Applications (IJMA) Vol.13, No. 4, August 2021

of the respondent strongly agree that the repetition of narration and question instruction voiceover function is useful and $18.8 \%$ of the respondents also agree about it.

Table 6. Result Finding of Functionality Section

\begin{tabular}{|c|c|c|c|c|c|}
\hline \multirow[b]{2}{*}{ Question Item } & \multicolumn{5}{|c|}{ Scale } \\
\hline & $\begin{array}{l}\text { Strongly } \\
\text { Disagree }\end{array}$ & Disagree & Neutral & Agree & $\begin{array}{c}\text { Strongly } \\
\text { Agree }\end{array}$ \\
\hline a) The animation of characters helps attract children to read & 0 & 0 & 6.3 & 37.5 & 56.3 \\
\hline $\begin{array}{l}\text { b) The content in the 'Alphabet' feature is useful and easy to } \\
\text { learn new words }\end{array}$ & 0 & 0 & 6.3 & 25 & 68.8 \\
\hline $\begin{array}{l}\text { c) 'Quiz' feature helps to remember words you've learned on } \\
\text { 'Alphabet' feature }\end{array}$ & 0 & 6.3 & 6.3 & 18.8 & 68.8 \\
\hline $\begin{array}{l}\text { d) Repetition of narration and question instruction } \\
\text { voiceover function is useful }\end{array}$ & 0 & 0 & 6.3 & 18.8 & 75 \\
\hline
\end{tabular}

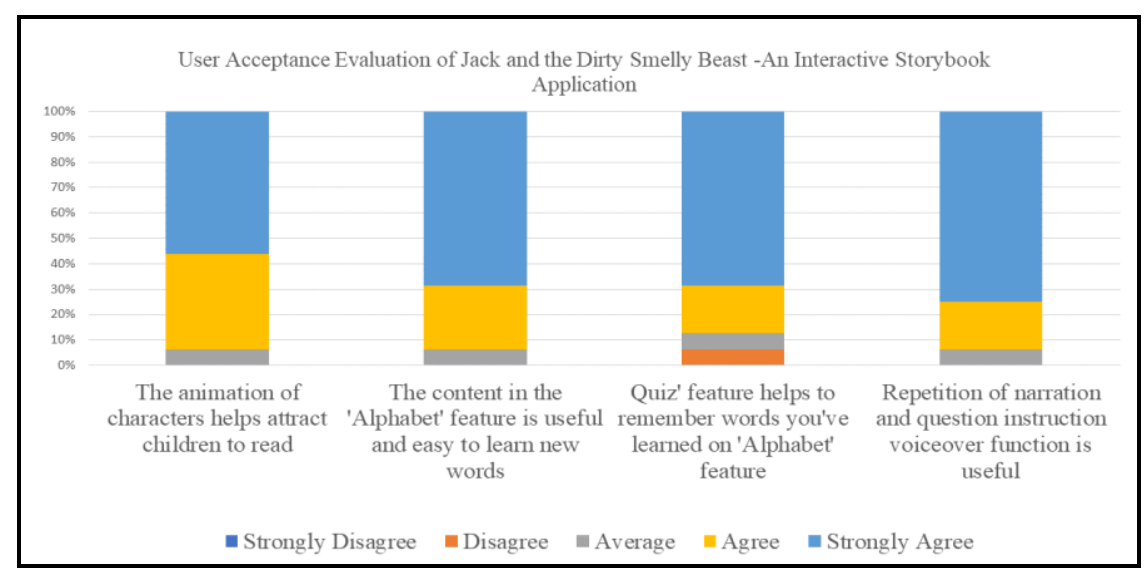

Figure 14. Bar Chart of Functionality Section Results

\subsection{Findings on Conclusion Section}

Table 7 and Figure 15 respectively show the result of the conclusion section of the questionnaire. A majority of the respondents comprising of $62.5 \%$ strongly agree that this application can induce the user to read more and $68.8 \%$ of the respondents also strongly agree that this application can also improve the user's literacy skills.

Lastly, the respondents strongly agree (75\%) and agree (25\%) that they are very satisfied with the application of the results. The total percentage of respondents who are satisfied with the application comprise of $75 \%$ (strongly agree) and $25 \%$ (agree).

Table 7. Result Finding of Conclusion Section

\begin{tabular}{lcccc}
\hline \multirow{2}{*}{ Question Item } & \multicolumn{3}{c}{ Scale } \\
\cline { 2 - 5 } & $\begin{array}{c}\text { Strongly } \\
\text { Disagree }\end{array}$ & Disagree & Neutral & $\begin{array}{c}\text { Strongly } \\
\text { Agree }\end{array}$ \\
\hline Agree
\end{tabular}


The International Journal of Multimedia \& Its Applications (IJMA) Vol.13, No. 4, August 2021

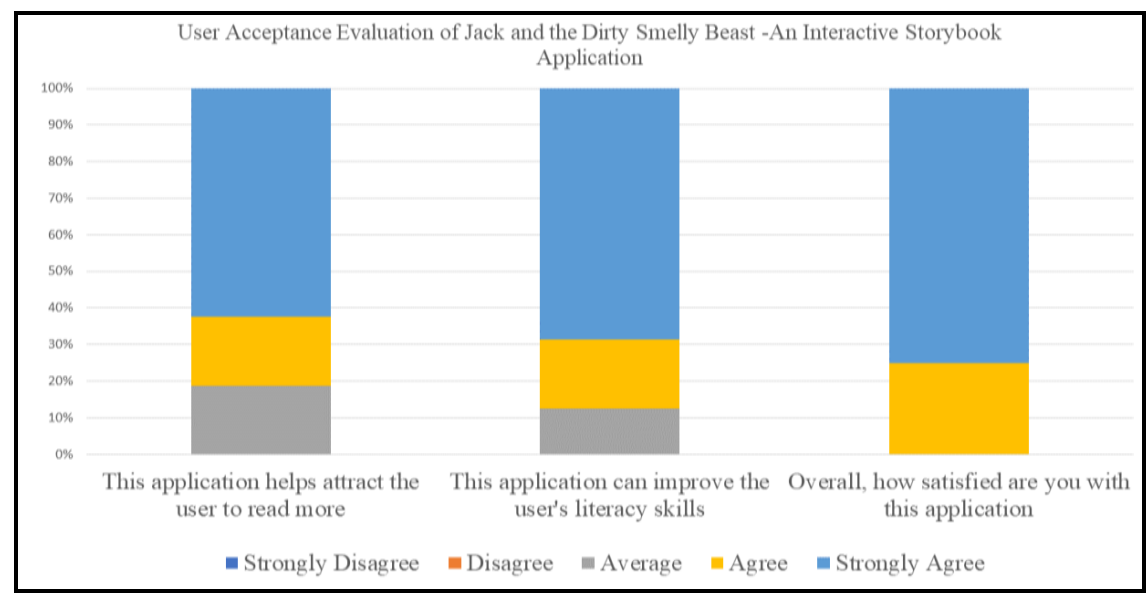

Figure 15. Bar Chart of Conclusion Section result

\subsection{Overall Findings}

The difficulty faced by people when using English language in their daily life, has led to the development of 'Jack and The Dirty Smelly Beast' application, is the solution to encourage an early education for foreign language literacy. This application, developed using Rapid Prototyping methodology, serves as a basis to identify faults and to improve the quality of the application.

Overall, it can be concluded that this application has achieved its objectives since most of the respondents are satisfied with its functionality, interface design and content of the application. However, various parts of the application can be further improved based on the feedback and suggestions before it can be fully utilised.

Based on tests carried out, several key areas of improvements have been identified for further development on the application. Additionally, a list of recommendations has been compiled based on feedback and suggestions from the respondents. Table 8 summarizes the limitation and recommendation for the 'Jack and The Dirty Smelly Beast' application:

Table 8. Result Finding of Conclusion Section

\begin{tabular}{lll}
\hline \multicolumn{1}{c}{ Limitation } & \multicolumn{1}{c}{ Recommendation } \\
\hline 1) $\begin{array}{l}\text { Young children might have difficulty to use and need a } \\
\text { guideline from their guidance to use this application. }\end{array}$ & $\begin{array}{l}\text { Add more application's content like more stories for } \\
\text { users to read and vocabulary word to learn so they will } \\
\text { us) } \begin{array}{l}\text { Short and lack of stories for users to read and } \\
\text { vocabulary words to learn. }\end{array}\end{array}$ & $\begin{array}{l}\text { 2) } \\
\text { Instead just a picture and word, vocabulary mode } \\
\text { should have an example and meaning for each word to }\end{array}$ \\
$\begin{array}{ll}\text { even though they just want to use quiz mode or } \\
\text { vocabulary mode only. }\end{array}$ & 3) $\begin{array}{l}\text { make it more attractive. } \\
\text { Add a character which will guide the users when they } \\
\text { first time using the application which will explain each } \\
\text { function and button in it. }\end{array}$ \\
\hline
\end{tabular}

In addition, respondents agreed that the 'Jack and The Dirty Smelly Beast' application has various advantages that children can benefit when using it. Some of the advantages are:

1. This application can be used anytime and anywhere since it was developed as a mobile app which can be installed on Android system which does not require internet connection to use. 
The International Journal of Multimedia \& Its Applications (IJMA) Vol.13, No. 4, August 2021

2. The users will be able to read, listen to the story and interact with the characters in the storybook when using this app.

3. The users can practice and learn new English words with the help of illustration and pronunciation audio.

4. The users can also test their vocabulary knowledge by playing quiz games.

\section{CONCLuSions}

In general, this research shows that 'Jack and The Dirty Smelly Beast' application is a useful app for attracting young children to read and learn a foreign language, thus confirming that all the objectives of this research have been successfully achieved. Through the development of this app, many things can be learned and improved based on the feedback and recommendation from the users for a better quality of app to be developed in future. It is envisaged that the development of this application can encourage the development of more education software in order to enliven children to foster a love for reading and to capture their interest and curiosity.

\section{REFERENCES}

[1] Wahi, W., \& Mohd. Sidek, H. (n.d.). The Malaysian EFL education: A brief historical review and literacy issues. Asian Social Science, 5. https://doi.org/10.5430/sass.v5n1p21

[2] Muhammad, M. M., Jack, C. S., \& Hamzah, S. G. (2017). The implementation of the Fulbright English teaching assistant program in Malaysia: An evaluation on students' language proficiency. Int. j. Adv. Appl. Sci, 4(6), 121-129. https://doi.org/10.21833/ijaas.2017.06.017

[3] Mohd Asraf, R., Abdullah, H., \& Mat Zamin, A. A. (n.d.). Literacy among Malaysian primary schoolers: How do boys perform relative to girls? International Electronic Journal of Elementary Education, 9, 225-238.

[4] Azman, H. (2016). Implementation and challenges of English language education reform in Malaysian primary schools. The Southeast Asian Journal of English Language Studies, 22, 65-78. https://doi.org/10.17576/3L-2016-2203-05

[5] Takacs, Z., Swart, E., \& Bus, A. (2014). Can the computer replace the adult for storybook reading? A meta-analysis on the effects of multimedia stories as compared to sharing print stories with an adult. Frontiers in Psychology, 5, 1366. https://doi.org/10.3389/fpsyg.2014.01366

[6] Prasetya, D., \& Hirashima, T. (2018). Design of multimedia-based digital storybooks for preschool education. International Journal of Emerging Technologies in Learning (IJET), 13, 211. https://doi.org/10.3991/ijet.v13i02.8188

[7] Haksız, M., \& Demirok, M. (2016). Computer usage status of special education tutors in teaching how to read and write: The example of Nicosia Province. Procedia Computer Science, 102, 635-641. https://doi.org/10.1016/j.procs.2016.09.454

[8] Serafini, F., Kachorsky, D., \& Aguilera, E. (2016). Picture books in the digital age. The Reading Teacher, 69. https://doi.org/10.1002/trtr.1452

[9] Sargeant, B. (2013). Interactive storytelling: How picture book conventions inform multimedia book app narratives. Australian Journal of Intelligent Information Processing Systems, 13, $29-35$.

[10] Mahadzir, N. N. N. (2013). The use of augmented reality pop-up book to increase motivation in English language learning for national primary school. IOSR Journal of Research \& Method in Education (IOSRJRME), 1(1), 26-38.

[11] Papadaki, E., Zabulis, X., Ntoa, S., Margetis, G., Koutlemanis, P., Karamaounas, P., \& Stephanidis, C. (2013, July 15-19). The book of Ellie: An interactive book for teaching the alphabet to children [Paper presentation]. IEEE ICMEW 2013, San Jose, CA, USA. https://doi.org/10.1109/ICMEW.2013.6618341

[12] Naufal, M. F., \& Kusuma, S. F. (2016). Interactive digital storybook for increasing children reading interest of Indonesian folklore. Jurnal Informatika dan Multimedia. 8(1).

[13] Yokota, J., \& Teale, W. (2014). Picture books and the digital world. The Reading Teacher, 67. https://doi.org/10.1002/trtr.1262 
The International Journal of Multimedia \& Its Applications (IJMA) Vol.13, No. 4, August 2021

[14] Liao, C. N., Chang, K. E., Huang, Y. C., \& Sung, Y. T. (2019). Electronic storybook design, kindergartners' visual attention, and print awareness: An eye-tracking investigation. Computers \& Education. 144, 103703.

[15] Yokota, J. (2013). From print to digital? Considering the future of picture books for children. In G. Grilli (Ed.). Bologna: Fifty years of children's books from around the world. Bologna: Bononia University Press. 52, 443-449.

[16] Støle, H., Mangen, A., \& Schwippert, K. (2020). Assessing children's reading comprehension on paper and screen: A mode-effect study. Computers \& Education, 103861. https://doi.org/10.1016/j.compedu.2020.103861

[17] Cekaite, A., \& Bjork-Willen, P. (2018). Enchantment in storytelling: Co-operation and participation in children's aesthetic experience. Linguistics and Education, 48, 52-60. https://doi.org/10.1016/j.linged.2018.08.005

[18] Wanderful Storybooks (Version 1.4) [Mobile application software]. Retrieved from https://apps.apple.com/us/app/wanderful-storybooks/id583696319

[19] Mohammad Farid, N. (2016). Interactive digital storybook for increasing children reading interest of Indonesian folklore. Vol 8. https://web.archive.org

[20] Educa Studio (2014). Hare \& Tortoise, the Interactive Storybook (Version 5.0.0) [Mobile application software]. https://play.google.com/store/apps/details?id=com.educastudio.cerikelincidankurakura\&hl=en

[21] Fox \& Sheep. (2015). Lucy \& Pogo Animal Storybook (Version 2.0) [Mobile application software]. https://apps.apple.com/us/app/lucy-pogo-animal-storybook/id976348415

[22] Ginger Whale (2011). Sleepy Mole's Moving Day (Version 3.0) [Mobile application software]. Retrieved from https://apps.apple.com/app/sleepy-moles-movingday/id473172561?ls=1

[23] Knoop-van Campen, C. A. N., Segers, E., \& Verhoeven, L. (2020). Effects of audio support on multimedia learning processes and outcomes in students with dyslexia. Computers \& Education, 150, 103858. https://doi.org/10.1016/j.compedu.2020.103858

[24] Guan, N., Song, J., \& Li, D. (2018). On the advantages of computer multimedia-aided English teaching. Procedia Computer Science, 131, 727-732. https://doi.org/10.1016/j.procs.2018.04.317

[25] Thorn, A. (2020). Scripting with C\# in Godot: Common Tasks. In: Moving from Unity to Godot. Apress, Berkeley, CA. 53-103. https://doi.org/10.1007/978-1-4842-5908-5_3

[26] Christopoulou, E., \& Xinogalos, S. (2017). Overview and comparative analysis of game engines for desktop and mobile devices. International Journal of Serious Games, 4, 21-36. https://doi.org/10.17083/ijsg.v4i4.194

[27] Thomas, P. Y. (2010). Towards developing a web-based blended learning environment at the University of. http://hdl.handle.net/10500/4245

[28] Valentini, A., Ricketts, J., Pye, R. E., \& Houston-Price, C. (2018). Listening while reading promotes word learning from stories. Journal of Experimental Child Psychology, 167, 10-31. https://doi.org/10.1016/j.jecp.2017.09.022

[29] Scherer, R., Siddiq, F., \& Sánchez Viveros, B. (2020). A meta-analysis of teaching and learning computer programming: Effective instructional approaches and conditions. Computers in Human Behavior, 109, 106349. https://doi.org/10.1016/j.chb.2020.106349

\section{AuTHORS}

Indah Fakhrani Arpin is a university student majoring in Bachelor of Software Engineering (Software Education) at Sultan Idris Education University, Malaysia. Her interests include graphic arts, multimedia projects (especially animation), indie games, and picture books!

Maizatul Hayati Mohamad Yatim is an associate professor of Human-Computer Interaction in Computing Department, at Sultan Idris Education University, Malaysia. Her research interests are specifically on game design and development, game usability, and game-based learning. She received her Ph.D. in Computer Science from Otto-vonGuericke University of Magdeburg, Germany, her M.Sc. in Information Technology, and her bachelor in Information Technology both from Northern University of Malaysia.
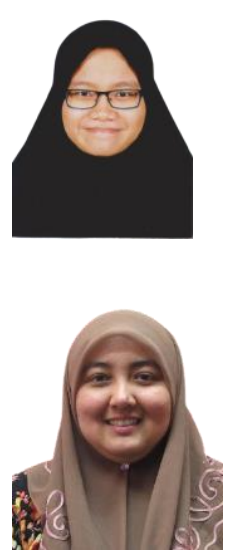